\title{
Contributions to the study of the Muisca calendar
}

\author{
Manuel Arturo Izquierdo \\ Université de Montréal, Département d'Anthropologie, \\ 3150, rue Jean-Brillant, Montréal H3T 1N8, Canada \\ email: ma.izquierdo@umontreal.ca
}

\begin{abstract}
The aim of this work is to review and expand upon the model proposed by Father José Domingo Duquesne de la Madrid (1745-1821) regarding the calendar of the pre-Columbian Muisca culture of central Colombia. This model was dismissed by scholars in the late 19th century when it was called just a simple invention of a clergyman; however, a detailed analysis shows that his interpretation of the calendar was based on genuine ethnographic information. According to Duquesne, this calendar was based on a series of moons whose multiples are 5, 20 and 37. These multiples generate time series that can be comparable to our years (37 moons), centuries (740 moons, or 59.8 years) and millennia (14800 moons or 1196 years). According to the information provided, these long time spans can be tracked up to a period of 74000 moons (5978 years). The work of Duquesne provides us some clues about the state of timekeeping traditions in pre-Columbian societies of the Intermediate Area.
\end{abstract}

Keywords. archaeoastronomy, Muisca, Colombia, calendar, Intermediate Area

\section{Introduction}

The Muisca Culture was one of most prominent pre-Columbian cultures of the Intermediate Area, and despite the extensive historical information and literature concerning this society, the subject of their timekeeping system or calendar has not been fully developed. The research work describes here develops a topic that formed part of my Master's degree in Anthropology (Université de Montréal), completed in 2008.

\section{Former ethnohistorical sources}

Ethnohistorical sources concerning the early Spanish colony of Nueva Granada (now Colombia) are not very informative on the topic of the Muisca calendar. Some chroniclers, such as Bishop Lucas Fernandez de Piedrahita, made a chronology of the lineages of the Muisca rulers based on "the computation of moons that the natives make" (Piedrahita 1666) allowing us to think that the Muisca timekeeping system was based on the moon. Another previous chronicler, Fray Pedro Simón, author of the most important chronicle of the Spanish conquest of Colombia Noticias Historiales de las conquistas de Tierra firme en las Indias Occidentales (1626), provides us with the earliest description of the Muisca year, telling us that the Muisca had a lunar year, named Chocan, used extensively in agriculture:

"...they had also a year of twelve moons or months, that began in January and finished in December, as cleverly than us whom use to start it at such a month, unlike the Roman calendar that began in March. So, they began it in January, because, being a dry season, they started to farm and prepare the land, in order to cultivate it in the waning moon of March, which is when the first rains of the first wet season of this land begin. And, from 
January's moon when they began to sow, until December, when they harvested, there was a span of twelve moons, the so called Chocan, which means the same we name year, and in order to refer to the previous years, they said Chocamana, and for the current year Chocamata..." (Simón, Noticias Historiales 4, chap. IX, p. 306)

Unfortunately, Simón does not provide us further details about the calendar or the activities linked to its use, except perhaps, a brief mention of a ceremony called the Huan, which was apparently associated with the December solstice (Correa 2004). Following the work of Simón, the topic does not seem to have been touched upon further by chroniclers for some two centuries. Near the end of the 18th century a catholic priest named José Domingo Duquesne proposed the most complete, but controversial, description of the Muisca timekeeping system thus far produced.

\section{José Domingo Duquesne}

Duquesne had a profound interest in the study of the native American cultures and can be considered to be one of the pioneers of archaeology in Colombia. During his years of service in the Indian villages of Lenguazaque and Gachancipá, the priest gained the confidence of the late native descendants of the Muisca people, who communicated to him the knowledge of their ancient calendar, which was probably kept alive by means of oral tradition (Zerda 1884: 278).

This experience lead Duquesne to write a dissertation in 1795, dedicated to José Celestino Mutis (the most important scientific figure of Nueva Granada), concerning the Muisca Calendar, wherein he described and analyzed the timekeeping information provided by his native informants. The quality of this work impressed the famous naturalist Alexander von Humboldt, who met Duquesne during his visit to Santafé in 1801. Years later, Humboldt used Duquesne as the source of the fourth chapter of his book Sites des cordillères et monuments des peuples indigènes de l'Amérique (1868) in which he presented an analysis of the calendar and described some personal communications from the priest. Following this, Duquesne's manuscript was published by Colonel Joaquín Acosta as an appendix of his book Compendio Histórico del descubrimiento y colonización de la Nueva Granada, published in 1848. In 1884, Liborio Zerda produced a series of unpublished manuscripts written by the clergyman in the Papel Periódico Ilustrado magazine, which seem to be documents written prior to the submission of Duquesne's work to Mutis. These are his only known published works to the date.

Despite the ethnographic details that Duquesne provided in his work, he was strongly criticized, near the end of the 19th century, by an important scholar named Vicente Restrepo. Restrepo considered that Duquesne's dissertation gave an inaccurate description of the Muisca calendar because it did not explicitly correlate with the chronicles by Pedro Simón and he concluded that it was simply an "invention of honourable fantasy" (Restrepo 1892: 3). This criticism is, however, contestable by current standards of ethnography and ethnohistory. For Restrepo the only valid source of information was the colonial chroniclers, a situation that allowed him to deny the importance of oral tradition:

"The Spanish conquest ended in the complete subjugation of Muisca Nation. No part of it remained autonomous in order to retain its language, beliefs and traditions. Everybody, either forced or voluntarily adopted the victor's language and religion ... When Doctor Duquesne served as parish priest in some indian villages, he just found poor and ignorant people that could not teach him anything about their ancestors' knowledge ... the generations that followed two and a half centuries had forgotten everything, even their own language ... What the illiterated indians from Turmequé, Lenguazaque and Gachancipá could teach him about such convoluted subjects as etymology, astronomy and theogony, which his studies were about?" (Restrepo 1892: 4, 6) 
Surprisingly, despite the weakness of Restrepo's arguments, his conclusions were widely adopted and prevailed in academia into the twentieth century. Duquesne's work, on the other hand, was broadly deemed an "historical curiosity ... despite that currently it is proved that it has no scientific basis" (Lloreda 1992: 13).

Contrary to common belief, Duquesne's native informants succeeded in teaching him important details concerning the Muisca calendar. Recent research shows that, in order to properly understand Duquesne's work, it is necessary to consider it as the outcome of an analytical exercise made by an 18th-century scholar, who tried to fit a corpus of calendrical and astronomical information that belonged to a different cultural tradition into the European canon of astronomy (Izquierdo 2008).

\section{Duquesne: numbers and time}

\subsection{The numbers}

One of the central reasons that Duquesne's work has often been dismissed by scholars is undoubtedly the fact that it is difficult to read his texts. In fact, one of the more confusing things about his work is the treatment he gives to the numbers, whose names in the Muisca language are used indeterminately to denote days, months, and probably, asterisms. In order to better understand this problem, it is necessary here to briefly comment on the number system of the Muisca. In addition to Duquesne's work, colonial grammars of Muyscubun (the native name for the Muisca language), such as the Gramática en la lengua general del Nuevo Reyno, llamada mosca by Fray Bernardo de Lugo (1619) and the 17th-century anonymous manuscript no. 158 of the Biblioteca Nacional de Colombia (González 1987), all state that the Muisca had a vigesimal numbering system, in which the names of the first 10 numbers are given as: Ata (1), Bosa (2), Mica (3), Muihica (4), Hisca (5), Ta (6), Cuhupcua (7), Suhusa (8), Aca (9), and Ubchihica (10) (using Duquesne's orthography). To indicate quantities in the range 11 to 19 , the same series of names is used again with the addition the quihicha prefix. The number 20, that could well be named as quihicha ubchihica, was named gueta instead, a word that means 'one group of twenty'. Further multiples of twenty are expressed as Guebosa (40), Guemica (60), Guemuihica (80), and so on. Intermediate values are composed following a cognitive plan based on the number twenty: for example, the number 31 is expressed as guetas asaqy quihicha ata-(guetas: 20$)+($ quihicha ata: 11$)=31$ (note that after gueta an 's' had to be added, and asaqy is an additional infix that means 'and more') (Lugo 1619; González 1987: 162). Furthermore, Duquesne stated that the Muisca counted minor divisions of 5,10 and 15 :

"... As the mathematicians gave to the circle 360 degrees, because the ease of this number to be subdivided in smaller ones in order to form any calculation, so them [the Muisca] divided their accounts in four parts obtained in the same fashion, split in counts of fives. So their more privileged numbers were $5,10,15,20$, which they used to fix all their affairs ..." (Duquesne 1848: 407)

Another difficulty inherent in reading Duquesne's work is presented by his extensive use of the base names of numbers, without adding the corresponding prefixes and infixes. For example, when the clergyman talks about a month named as Cuhupcua (7), it is up to the reader to figure out if he is referring to the 7 th, the 17 th, or the 27 th element in a series of moons.

\subsection{The day and the week}

In his Noticias Historiales, Simón tell us that "the days were counted by suns, because it was the cause of them, thus so many suns were so many days; these were divided into three 
parts, morning, noon, and afternoon" (Simón 1626: 306). According to Duquesne, “... the artificial day was called sua, that is, a sun measured from sunrise to sunset" (Duquesne 1884: 221). Daylight was divided into two parts, one from sunrise until noon, and the other from the noon to sunset. Duquesne stated that the Muisca called these spans of time Suamena and Suameca, respectively, which is supported by Ezequiel Uricoechea's grammar and vocabulary (Uricoechea 1871). However, the Manuscript no.158 indicates that these terms are synonyms of 'afternoon' and provides the alternative term Zacoca for 'morning' (González 1987). Night was considered a different entity. The term for 'night' was $Z a$ which is supported by all sources, and as in the case for the day, night had two divisions: Zasca and Cagüi. The first one corresponds to the time span from sundown to midnight, and the second from midnight until dawn. According to the Manuscript no.158, the word Cagüi has the alternative meaning of 'morning star', therefore associating the second half of the night with the sighting of bright planets, especially Venus, which is often visible during the early morning.

The definition of the concept of the week in Muisca society is more problematic considering the available historical sources. Gonzalo Jiménez de Quezada, the Spanish conquistador of the Muisca territories, in his early chronicle Epitome de la conquista del Nuevo Reino de Granada (1960 [ca. 1548]) describes a week as consisting of ten days, dividing the span of a 30-day month into three sections:

"... They have distributed the times of months and years in a very convenient way. The first ten days of the month, they eat an herb known on the sea coast as hayo which supports and purges them of their illnesses. After these days, cleaned of the hayo, they work another ten days sowing their lands. And the remaining ten days of the month, are spent in their homes, talking and resting with their women ..." (Jiménez de Quesada 1960 [ca. 1548])

Simón, however, gives us a different version of the week which is similar to our contemporary 7-day week:

"... They counted the months by moons with its wanings and crescents, dividing each one of these in another two, such that there were four parts of the month or moon, in the same manner we divide it by four weeks ..." (Simón 1627)

In another context, Duquesne described a 20-day span that was used in the context of war and for ritual activities:

"... When they declared war, they stayed for twenty days on the battlefield, singing and pleased with the hope of victory, but if they lost the battle, remained on the same battlefield another twenty days crying for their dark and unfortunate fate..." (Duquesne 1884: 211)

This is supported by the chronicler Juan Rodriguez Freyle (1636) who in his work El Carnero recounts that on the eve of a battle between the forces of the chiefs Guatavita and Bogotá, the Muisca priesthood convinced the factions that "it would be right to pacify the gods before the battle occurred, and in order to do it, it should be fair to allow a truce of twenty days or more" (Freyle 1636: 73). Referring to these rituals he related that "the strength of that feast lasted twenty days or more, as time prescribed, with great rituals and ceremonies." (ibid.: 84)

Considering both the accounts of Duquesne and Freyle, a period of twenty days appears to be an important week-like time span for the Muisca. However, Duquesne further confuses the situation when he subsequently affirms that for the Muisca "the week was of three days, and its use is known because every three days they used to hold a market in Turmequé, place that belongs to Guatavita." (Duquesne 1884: 221).

It is evident that such differing versions of the week are the product of an underlying attempt to match the European idea of the week to the diverse time spans associated 
with the activities of Muisca society, which apparently were not regulated by any standardized timespan between day and month. The Manuscript no.158 supports this idea when it describes the translation to Muyscubun of expressions of time that involve the names of the days of the week: 'The next Sunday', Fasinga domingoca; 'He will come the Wednesday', Miércolesca hunga; and 'I will go this Friday', Viernesc inanga. Notice that the translations appeal to the corresponding Spanish words for Sunday, Wednesday and Friday (Domingo, Miércoles, Viernes) integrated into the native grammar, attesting to the fact that such alien concepts were being forcibly introduced into the Muisca language. As will be outlined in the folowing sections, the levels of resolution of the Muisca timekeeping system can be considered as days, months, years and centuries.

\subsection{The lunar month}

Duquesne explains that the Muisca used their fingers to perform counts in order to determine the times of the lunar quarters and heliacal rise and set of the moon, which corresponds well with Simón (see section 4.2), who stated that the month was divided into quarters. Following him, one would expect the days for the lunar phases to form regular intervals, which curiously is not the case. In fact, the days for the lunar phases described by Duquesne exhibit in some cases errors of up to three days when compared with the real lunar phase dates (see Table 1). Furthermore, the versions of Duquesne's texts published by Acosta in 1848 and Zerda in 1884 offer different versions of the days for the lunar phases, which suggest that Duquesne received two different formulae from his informants for accounting the same timespan (see Izquierdo 2008 for a detailed analysis of these texts).

\begin{tabular}{l|r|c|c|}
\hline & Real day & Duquesne (1848) & Duquesne (1884) \\
\hline Cuadrature & 7.3827 & 7 th & 10 th \\
Conjunction & 14.7654 & 15 th & 14 th \\
Cuadrature & 22.1482 & 23 th & 20th \\
Opposition & 29.5309 & 30 th & 3rd \\
\hline
\end{tabular}

Table 1. Lunar phases for the Muisca according to Duquesne. The numbers correspond to the number of days in a series of 30 days. The Real day column is calculated in steps of exactly $\frac{1}{4}$ of the lunar synodic period.

In the text from 1848, Duquesne states that Ubchihica was the first element of a series of days describing the lunar quarters; this number must be translated as thirty (Guetas asaqy Ubchihica $(20+10)=30)$, owing to the fact that series started on the last day of the previous lunation, which indicates that for the Muisca the month was composed of thirty days.

This leads to the question of how the Muisca dealt with the difference of about half a day between the 30-day span and the real span of a synodical lunar period (29.53089d). As the accumulation of this error would be clearly visible within a period of a few months, a correction probably had to be introduced, most likely accounting 30 days for one month and 29 for the next, however, such a correction must be considered hypothetical at present.

\subsection{Years}

The Muisca year system described by Duquesne is, at first glance, different from the system described by Simón. Duquesne tell us about a timekeeping system that used two concurrent types of years, both based on lunar months, but with differing lengths. The 
first one was the so-called Zocam, a name that apparently coincides with the year reported by Simón, but according to Duquesne it was twenty moons long instead of twelve. Unfortunately, the clergyman did not provide further details explaining this difference. Humboldt differentiated them and proposed the name Rural year to designate the 12 moon year described by Simón and Vulgar year for the 20-moon span of Duquesne (1848: 481).

The second type of year had 37 moons, named the Acrotom year by Duquesne. According to him, this year was the sum of 3 consecutive lunar years (or rural years), plus an intercalary month, which would produce a span of 1092.63 days, which is close to a span of 3 solar years (1095.75d). This year was considered by Duquesne as a device used by the Muisca priests to achieve synchronization between the lunar and solar cycles. Humboldt agrees with this last proposition and calls it the Year of the Priests (1868: 465). In my work, the terms Rural, Zocam, and Acrotom were retained to denote the time spans of 12,20 , and 37 moons respectively, despite the fact that, etymologically, the word zocam means 'year' in a general sense.

\begin{tabular}{|c|c|}
\hline Time span & Length \\
\hline $\begin{array}{l}\text { Rural Year } \\
\text { Zocam Year } \\
\text { Acrotom Year }\end{array}$ & $\begin{aligned} & 12 \varsigma \\
& 20 \varsigma \\
12 \varsigma+12 \varsigma+12 \varsigma+1 \varsigma= & 37 \S \\
20 \varsigma+17 \varsigma= & 37 \varsigma\end{aligned}$ \\
\hline $\begin{array}{l}\text { Zocam Century } \\
\text { Acrotom Century }\end{array}$ & $\begin{array}{l}20 \times 20 \varsigma=400 \varsigma \\
20 \times 37 \varsigma=740 \varsigma\end{array}$ \\
\hline
\end{tabular}

Table 2. Muisca years and centuries according to Duquesne.

\subsection{Centuries}

Based on these types of year, Duquesne proceeded to describe two kinds of 'centuries', created by the multiplication of both the Zocam and Acrotom years by 20. The first one, based on the Zocam Year, corresponded to 400 moons $(20 \times 20)$. The second, based on the Acrotom years, corresponded to 740 moons $(20 \times 37)$. Duquesne affirmed that this century corresponded to 60 solar years, which is an approximation, because the real duration of this span is 59.83 solar years. This century was divided by the Muisca priests into quarters of 185 moons each, spans that Duquesne called Astronomical Revolutions. Following the notation I retained for the years, I will refer these centuries as the Zocam Century and Acrotom Century.

\section{Duquesne: hidden structures}

The relevance of Duquesne's work becomes even more obvious after a careful analysis of his texts, wherein additional structural components of this calendar are exposed, structures that apparently the priest did not realize were in existence and that provide evidence that his work was based on authentic data obtained from ethnographic sources.

\subsection{The Cycle of Ata}

In analyzing the text, a section that came to be of great interest was the description of the sequence of moons required for the Acrotom Century, in order to have a calendar 'round' of 37- and 20-moon cycles, synchronized again. Duquesne wrote: 
"[The Acrotom years method] would have been confusing, if it had not been established under a fixed procedure with simple and general rules. It had four signs assigned to achieve such a goal: First Ata; then Suhusa, in the three last [signs] of the year, which they called the tail; Aca and Gueta, which were those that concluded the twenty moon year and that we therefore can call terminals. So, beginning by Ata, corresponded the number 17 of the next [Zocam year] one to Cuhupcua, who by this intercalation they properly called the 'deaf person', and the sowing was made in the next one, Suhusa 18. Spent the year of twenty moons, corresponded the number 17 of the next one to Muihica, the 'blind person', and the sowing and the representation of the first month passed to Aca. In the biennium of this one, corresponded the number 17 to Hisca, and Gueta entered in the place and function of Aca; in its biennium it was 17, Ta, and the turn came back to the first one, Ata ..." (Duquesne 1884: 218)

As the Acrotom Century consists of a round of 37 moons (an Acrotom Year) repeated 20 times, it would yield 740 combinations before returning to the starting point of the round. In this process, Duquesne tells us that the Muisca considered the numbers Ata (1), Suhusa (8), Aca (9), Gueta (20), to be the 'name' of the first moon of each Acrotom year along an Acrotom Century. Starting a century in Ata (the 1st moon), after 37 moons, the 2nd Acrotom year will begin on the 38th moon and correspond to the name Suhusa, then the 3rd year will correspond to Aca, and the 4th year would be Gueta. Following this, the next year would return to Ata. However, reviewing this sequence, it becomes evident that this cycle is not an Acrotom Century. In fact, the given values for the three final years do not correspond to the expected moons: the 3rd year starts on the 79th moon (it should be the $75 \mathrm{th}$ ), and the 4 th year starts on the 120 th (which should be the 116th). This sequence describes a span of 160 moons, which is quite a different time span from an Acrotom Century which is 740 moons long.

\begin{tabular}{|c|c|c|c|}
\hline ATA & SUHUSA & $\mathrm{ACA}$ & GUETA \\
\hline (01) ATA & (38) SUHUSA & (79) Q. ACA & (120) GUETA \\
\hline (02) BOSA & (39) ACA & (80) GUETA & (121) ATA \\
\hline (03) MICA & (40) UBCHIHICA & (81) ATA & (122) BOSA \\
\hline (04) MUIHICA & (41) ATA & (82) BOSA & (123) MICA \\
\hline (05) HISCA & (42) BOSA & (83) MICA & (124) MUIHICA \\
\hline (06) TA & (43) MICA & (84) MUIHICA & (125) HISCA \\
\hline (07) CUHUPCUA & (44) MUIHICA & (85) HISCA & (126) TA \\
\hline (08) SUHUSA & (45) HISCA & (86) TA & (127) CUHUPCUA \\
\hline (09) ACA & (46) TA & (87) CUHUPCUA & (128) SUHUSA \\
\hline (10) UBCHIHICA & (47) CUHUPCUA & (88) SUHUSA & (129) ACA \\
\hline - & - & & - \\
\hline - & - & - & - \\
\hline (35) Q. मंISCA & (72) Q. BOSA & (113) Q. $\dot{\mathrm{MICA}}$ & (154) O. MÜIHICA \\
\hline (36) Q. TA & (73) Q. MICA & (114) Q. MUIHICA & (155) Q. HISCA \\
\hline (37) Q. CUHUPCUA & (74) Q. MUIHICA & (115) Q. HISCA & (156) Q. TA \\
\hline & (75) Q. HISC & (116) Q. TA & (157) Q. CUH \\
\hline & (76) Q. TA & (117) Q. CUHUPCUA & (158) Q. SUHUSA \\
\hline & $\begin{array}{l}\text { (77) Q. CUHUPCUA } \\
\text { (78) Q. SUHUSA }\end{array}$ & $\begin{array}{l}\text { (118) Q. SUHUSA } \\
\text { (119) Q. ACA }\end{array}$ & $\begin{array}{l}\text { (159) Q. ACA } \\
\text { (160) GUETA }\end{array}$ \\
\hline
\end{tabular}

Table 3. Cycle of Ata

In order to start each year on the prescribed numbers or 'symbols', this new cycle, denominated as the Cycle of Ata (Izquierdo, 2008), requires that three sequences of 4 moons must be inserted at the end of the $2 \mathrm{nd}$, 3rd and 4 th years, which is equivalent 
to an intercalation of 12 moons (a Rural year) after four Acrotom Years (see Table 3). Consequently, counting 20 Acrotom years (an Acrotom Century) as a reference, and adding these intercalary moons to each 4 Acrotom years, will produce a count of 2 Zocam Centuries or 800 moons. Such an 800-moon span would be akin to the Acrotom Century in the role of being a 'kind of century' span, and is referred as Extended Zocam Century (Izquierdo 2008). The Cycle of Ata is thus a count that really relates to the Zocam Year and its multiples, but uses the Acrotom years as a formalism. Because the Cycle of Ata (160 moons) is $\frac{1}{5}$ of an Extended Zocam Century, it could be argued that it divided such an 800-moon 'century' into five parts, conceptually similar to the Astronomical Revolutions that divided the Acrotom Century into four parts (see Table 4).

\begin{tabular}{l|l|c}
\hline \multicolumn{1}{c|}{ Century type } & \multicolumn{1}{c|}{ Division } & Length \\
\hline Acrotom Century & Astronomical Revolution & $7408 \div 4=185 ه$ \\
Extended Zocam Century & Cycle of Ata & $8008 \div 5=1608$ \\
\hline
\end{tabular}

Table 4. Divisions of the Muisca Centuries.

In my opinion, the way that Duquesne described the Cycle of Ata without defining it as a different entity from the Acrotom Century, firmly supports the idea that, far from inventing a calendar, the priest was indeed describing an authentic timekeeping system whose technical details contained hidden structures he did not fully understand.

\subsection{Long-term periods}

Pedro Simón provides further information that, when interpreted through the framework derived from Duquesne's work, indicates that the Muisca probably devised long-term spans beyond the centuries. His historical account describes the myth of the coming of Bochica, the civilizing hero of the Muisca culture and mythological character similar to Quetzalcoatl in Mesoamerica or Wiracocha in the Central Andes.

In accordance with the traditions of the southern Muisca in Bogotá, Simón wrote:

"... a very true tradition that everybody has in this reign, is that an unknown old man, dressed in wool, with long hair and a beard down to his waist arrived twenty ages ago, and each age counted as seventy years ..." (Simón, Noticias Historiales 4, chap. III, p. 284)

and the version of the northern Muisca says:

"... four ages or Bxogonoa ago, a man came with the same shape and dress we described

in the lands of the Bogota ..." (Simón, Noticias Historiales 4, chap. IX, p. 314)

The citations refer to two different kinds of 'age' used to express the span since the coming of Bochica: one is called the 'age of seventy years' and the other called Bxogonoa. Many authors have unsuccessfully tried to make sense of these ages, but no apparent link to Duquesne has been found. For example, José Rozo (1997) estimates that such 'twenty ages' correspond to 1400 years and each Bxogonoa is 350 years. However, Rozo proposes that such time spans are unlikely, and concludes that they only indicate multiple ways to objectivize time among the northern and southern Muisca traditions.

In fact, the 70-year span described by Simón does not really match any of the periods described by Duquesne, except that such ages seem to represent something similar to century-like periods. Was this seventy year 'age' an alternative period unknown to Duquesne? I do not think so. Considering the framework described by Duquesne, it is plausible to think that maybe one of the scribes that copied the original manuscript of the Noticias Historiales before its publication at the end of the 19th century, or even Simón himself, may have misspelled the original word describing the value of such an 
age. In Spanish, the number 60 is written as sesenta, whilst 70 is written setenta, there is just a difference of one letter. An error of turning an $s^{\prime}$ into a $t$ ' is very plausible in the context of palaeographic documentation.

If we pursue this hypothesis, it can be assumed that such an age is sixty years long, which matches Duquesne's calculation perfectly and thus lead us to consider that it also corresponds to an Acrotom Century. Consequently, the Coming of Bochica may refer to a time of 20 Acrotom Centuries or 14800 moons (1196.63 solar years). Assuming now that the 20 ages of the southern Muisca correspond to the 4 Bxogonoa of the northern Muisca, we can deduce the value of a Bxogonoa as 3700 moons, which also corresponds to 185 Zocam years (or 100 Acrotom years), which are also equal to 5 Acrotom Centuries, giving a span of almost 300 solar years.

Another interesting clue is given by Duquesne, who also mentions another tradition related to Bochica, concerning The misterious dream of Bochica, that lasted "twenty times five twenties of years" (1884: 211). In fact, this tradition was mentioned by Humboldt as well, who wrote: "Bochica, devoted to austere penances, lived one hundred muysca cycles, or two thousand years" (1868: 462). If for 'year' we understand an Acrotom Year, then for dream/life we have 74000 moons, which corresponds to twenty times the value of a Bxogonoa. Additionally, the dream/life corresponds to 3700 Zocam years, 185 Zocam Centuries, or, as Humboldt argued, 100 Acrotom Centuries or 2000 Acrotom years. In solar years, it would correspond to 5978 years. We see the use of the numbers 185, 37 and 20 again, but expressing higher units of time.

\section{Discussion}

The authenticity of Duquesne's sources is validated when 'hidden' components of the Muisca timekeeping system, the Cycle of Ata, are uncovered after a careful analysis of his texts. This analysis strongly suggests that instead inventing a calendar, the clergyman attempted to record a corpus of ethnographic information whose subtleties he did not fully understand. The hypothesis of the spelling error provides a way for us to reconcile the information given by Duquesne in relation to that of Simón, and allows for a better understanding of new aspects of the Muisca mythology in relation to time. This suggests that the 'dates' of both the 'coming' of Bochica and his 'mysterious dream' or 'life' are not real historical dates, but rather they are mythical time spans profoundly related to the arithmetical structure of the Muisca timekeeping system.

\begin{tabular}{|c|c|c|}
\hline Time span & | Moons | & Source \\
\hline \multicolumn{3}{|c|}{ Acrotom Family } \\
\hline $\begin{array}{l}\text { Rural Year } \\
\text { Acrotom Year } \\
\text { Astronomical Revolution } \\
\text { Acrotom Century } \\
\text { Bxogonoa } \\
\text { Coming of Bochica } \\
\text { Dream/life of Bochica }\end{array}$ & $\begin{array}{r}128 \\
378 \\
1858 \\
7408 \\
37008 \\
148008 \\
740008\end{array}$ & $\begin{array}{l}\text { Simón, Humboldt, Duquesne* } \\
\text { Duquesne } \\
\text { Duquesne } \\
\text { Duquesne } \\
\text { Simón } \\
\text { Simón } \\
\text { Duquesne, Humboldt }\end{array}$ \\
\hline \multicolumn{3}{|c|}{ Zocam Family } \\
\hline $\begin{array}{l}\text { Zocam Year } \\
\text { Cycle of Ata } \\
\text { Zocam Century } \\
\text { Extended Zocam Century }\end{array}$ & $\begin{array}{l}208 \\
1608 \\
4008 \\
8008\end{array}$ & $\begin{array}{l}\text { Duquesne } \\
\text { Duquesne* } \\
\text { Duquesne } \\
\text { Duquesne* }\end{array}$ \\
\hline
\end{tabular}

Table 5. Units of time of the Muisca timekeeping system. 
Following this analysis, we arrive at a complex picture of units of time that can be organized into two categories: one 'family' category that follows the Acrotom Year system, and another that follows the Zocam Year system (see Table 5). From this, a general organization of the Acrotom family is organized as value-couples, wherein the second value of a couple is 5 times the value of the first, identifying three orders of magnitude (see Table 6).

$$
\left.\begin{array}{llr}
\text { Acrotom year } & = & 37 \times 20^{0} \\
\text { Astronomical Revolution } & = & 5 \times 37 \times 20^{0}
\end{array}\right\} 1 \text { st order }
$$

Table 6. General organization of the Acrotom family

The Zocam family appears to be a set of 'independent' units of time. However, this idea perhaps exposes our current ignorance about this family. Recent works (Allen 2010) suggest that the Zocam year was a count based on the sidereal period of the Moon $(\& \mathrm{SID}=27.326661 \mathrm{~d})$, instead of the synodic one $(\varangle=29.53089 \mathrm{~d})$. In fact, it is very interesting to verify that $378(1092.63179 d)$ yields a span very close to 408 SID (1092.86644d), which immediately creates an equivalence between the Acrotom and the Zocam families; if the Muisca were aware of the lunar sidereal period, then probably both the Acrotom Century and the Extended Zocam Century referred to the same timespan of 59.83 years, leading us to speculate that the Muisca might have devised two notations to express time, one based on the synodic cycle of the moon and the other on the sidereal one. In fact, the use of the lunar sidereal cycle has already been suggested by Tom Zuidema (1977) for such contemporary cultures of the Muisca as the Inca Empire (in the Andes). Although the study of the interactions between the cultures of the Intermediate Area and the Central Andes and Mesoamerica has only been cursorily explored, the resemblances between the calendar described and the timekeeping traditions of the Central Andes and Mesoamerica are evident, suggesting that "when the Muiscas developed their own calendrical system, they eclectically incorporated concepts from the astronomical and arithmetic traditions of the main cultural centres of America, [which is evidenced by] the insistence to use lunar months (Andes) as base units of the 'calendar rounds' (Mesoamerica), which compose the Cycle of Ata and the Acrotom Century of the Muisca system" (Izquierdo 2008: 97).

Additionally, the relationship of the Muisca Calendar to other Colombian native groups must be taken into account. Ethnohistorical work on the traditions of other native societies neighbouring the Muisca, such as the Tayrona, Guane, Lache, Achagua and Panche is almost nonexistent; a comprehensive study of these groups will be necessary in order to allow for the analysis of the Muisca timekeeping system in conjunction with the cultural background of the Intermediate Area. Ethnographic work concerning contemporary groups linguistically related to the Muisca, such as the Kogi and the U'wa (ReichelDolmatoff 1950; Mayr 1987; Osborn 1995), shows that these groups have similar structures of arithmetic to those of the Muisca (in the case of the Kogi, with Mesoamerica, 
see Kelley \& Milone 2011: 433). The management of time and the understanding of astronomical phenomena both provide excellent starting points for future comparative work.

The present work must be understood, however, as a re-elaboration of Duquesne's model but not as a definitive model of the Muisca Calendar. Duquesne's model is the product of the reflections of a colonial clergyman on the memories of Muisca Indians of the late 18th century. We do not fully understand the circumstances in which he obtained his data, or how the native informants' vision of timekeeping could have been altered through three centuries of contact with Europeans. Additionally, factors such as the influence of historical accounts of the Spanish conquest of Peru and Mexico that he very probably read, and the diffusionist beliefs that were prevalent in his time, tracking the origins of Native American cultures back to ancient Israel and the ancient Egyptians, must be taken into account when attempting to understand his work.

Duquesne's model should be considered a reference point for the study of the preColumbian calendars of the northeastern Andes of Colombia. It will be necessary to undertake extensive archaeological research in order to verify and expand upon the model presented here, and in this way to complement our vision of the place of the Muisca calendar in the context of the timekeeping traditions of the pre-Columbian Americas.

\section{Acknowledgements}

I would like to thank the IAU, ISAAC and the Anthropology Department of the Université de Montréal for their grants that allowed me to present this work at the Oxford IX Conference.

\section{References}

Allen, J. 2010, Lost Calendar of the Andes: the Calendar of Tiwanaku and of the Muisca. Document online at http://www.atlantisbolivia.org/tiwanakuanimatedcalendar.htm.

Correa, F. 2004, El Sol del Poder: Simbología y Política entre los Muiscas del Norte de los Andes, Universidad Nacional de Colombia, Facultad de Ciencias Humanas, Bogotá.

Duquesne, J. D. 1848, Disertación sobre el calendario de los Muyscas, indios naturales de este Nuevo Reino de Granada. In J. Acosta, Compendio Histórico del Descubrimiento y Colonización de la Nueva Granada, Bogotá, pp. 405-419.

Duquesne, J. D. 1884, Anillo Astronómico de los Moscas. In L. Zerda, "El Dorado", Papel Periodico Ilustrado, 66, year III, pp. 278-318. Repr. 1947 by Ministerio de Educación de Colombia, Biblioteca Popular de Cultura Colombiana, Bogotá.

Freyle, J. R. 1636, El Carnero. Ed. Bedout (1985), Medellín.

González, M. E. 1987, "Diccionario y Gramática Chibcha." Manuscrito Anónimo de la Biblioteca Nacional de Colombia, Instituto Caro y Cuervo, Bogotá.

Humboldt, A. 1868, Sites des Cordillères et Monuments des Peuples Indigènes de l'Amérique, Legrand, Pomet et Crouzet, Paris.

Izquierdo, M. 2008, The Muisca Calendar: an Approximation to the Timekeeping System of the Ancient Native People of the Northeastern Andes of Colombia, Université de Montréal, Département d'Anthropologie, Montréal. Document online at http://arxiv.org/abs/0812.0574.

Jiménez de Quesada, G. 1960 [ca. 1548], Epítome de la conquista del Nuevo Reino de Granada. In J. Friede, Descubrimiento del Nuevo Reino de Granada y Fundación de Bogotá (15361539): Según Documentos del Archivo General de Indias, Sevilla, Imprenta del Banco de la República, Bogotá, pp. 261-273.

Kelley, D. \& Milone, E. 2011, Exploring Ancient Skies: a Survey of Ancient and Cultural Astronomy (2nd edn), Springer, New York.

Lloreda, D. 1992, Los Muiscas: Pasos Perdidos, Seguros Fénix, Bogotá. 
Lugo, F. B. 1619, Gramática en la Lengua General del Nuevo Reyno, llamada Mosca, Bernandino de Guzmán, Madrid.

Mayr, J. 1987, Contribución a la astronomía de los Kogi. In J. Arias (ed.), Etnoastronomías Americanas, Ediciones de Universidad Nacionextnal de Colombia, Bogotá, pp. 57-68.

Osborn A. 1995, Las Cuatro Estaciones. Mitología y Estructura Social entre los U'wa, Banco de la República, Museo del Oro, Bogotá.

Piedrahita, L. 1666, Historia General de las Conquistas del Nuevo Reino de Granada II, Chapter 1. Repr. 1881, Imprenta de Medardo Rivas, Bogotá.

Reichel-Dolmatoff, G. 1950, Los Kogi, Revista del Instituto Etnológico vol IV, nos. 1, 2, Bogotá.

Restrepo, V. 1892, Crítica de los Trabajos Arqueológicos del Dr. José Domingo Duquesne, Imprenta de la Nación, Bogotá.

Rozo, G. J. 1997, Espacio y Tiempo entre los Muiscas, El Buho, Bogotá.

Simón, F. P. 1626, Noticias Historiales de las Conquistas de Tierra Firme en las Indias Occidentales. Repr. 1882-92, Imprenta de Medrado Rivas, Bogotá.

Uricoechea, E. 1871, Gramática: Vocabulario, Catecismo I Confesionario de la Lengua Chibcha según Antiguos Manuscritos Anónimos e Inéditos, Maisonneuve i Cia, Paris.

Zerda, L. 1884, El Dorado. Repr. 1947, Ministerio de Educación de Colombia, Biblioteca Popular de Cultura Colombiana, Bogotá.

Zuidema, T. 1977, The Inca Calendar. In A. F. Aveni (ed.), Native American Astronomy, University of Texas Press, Austin, pp. 219-259. 